\title{
STOCHASTIC SIMULATION OF THE ECONOMIC VIABILITY OF FEEDLOT STEERS FED WITH DIFFERENT PROPORTIONS OF CONCENTRATE
}

\author{
SIMULAÇÃO ESTOCÁSTICA DA VIABILIDADE ECONÔMICA DO \\ CONFINAMENTO DE NOVILHOS ALIMENTADOS COM DIFERENTES \\ PROPORÇÕES DE CONCENTRADO
}

\section{Rodrigo Medeiros da SILVA ${ }^{1}$; Rodrigo Zaiden TAVEIRA ${ }^{2}$; Fabiano Nunes VAZ ${ }^{3}$; Edom de Avila FABRICIO ${ }^{4}$; Josiane Rodrigues MIOLLO ${ }^{5}$; Angelina CAMERA ${ }^{5}$; Paulo Santana PACHECO ${ }^{6}$}

1. Professor, Doutor, Bolsista BIP UEG, Universidade Estadual de Goiás - UEG, São Luiz de Montes Belos, GO, Brasil; 2. Professor, Doutor, UEG, São Luiz de Montes Belos, GO, Brasil; 3. Professor, Doutor, Universidade Federal de Santa Maria - UFSM, Santa Maria, RS, Brasil; 4. Doutorando em Zootecnia - UFSM, Santa Maria, RS, Brasil; 5. Graduanda em Zootecnia - UFSM, Santa Maria, RS, Brasil; 6. Professor, Doutor, UFSM, Santa Maria, RS, Brasil. pacheco.dz.ufsm@ hotmail.com

\begin{abstract}
The economic viability of feedlot zebu bulls, slaughtered at $450 \mathrm{~kg}$ after 90 days of feeding with diets consisting of different proportions of concentrate in dry matter (40, 60 or $80 \%$ ), was estimated using Monte Carlo simulations, with or without the inclusion of Spearman rank correlations among random input variables, stochastic dominance (DOM) and sensitivity analysis (SENS). The roughage used was chopped sugar cane. Cash flow with indicators of performance, and probability distributions of all items of cost and revenue (from 2003 to 2014), were used to stimulate net present value (NPV), the financial indicator. Latin hypercube sampling and a Mersenne Twister random number generator were employed for the simulation with 2000 interactions. The risk was found to be more accurately estimated when correlations between random input variables were included (probability of NPV $\geq 0 \pm$ standard deviation was $35 \pm 166.05 \%$ and $31 \pm 139.75 \%$ for the simulation without and with correlation, respectively). Considering this result, DOM and SENS were only carried out including these correlations. The expected value for NPV was similar between the different levels of concentrate (average USD -62/animal and NPV $\geq 0$ of 33\%) according to DOM analysis of simulations including correlations. From the SENS analysis, the final weight, finished cattle price, feeder cattle price and initial weight were the items with the greatest influence on NPV, regardless of the level of concentrate used, followed by intake and the cost-related items of diet and minimum rate of attractiveness. Based on the results obtained by simulation, the direct benefit of feedlot could be classified as high risk, suggesting the increased use of Monte Carlo simulation for decision-making.
\end{abstract} correlation.

KEYWORDS: Investment analysis. Investment project. Probabilistic analysis. Stochastic method. Rank

\section{INTRODUCTION}

According to estimates by Anualpec (2015), between 2006 and 2014 there was a 102\% increase in feedlot-finished cattle in Brazil, with this technology applied to approximately $10 \%$ of total cattle slaughtered. Many states in Brazil have adopted feedlot technology, aimed at determining their direct benefit. These are mainly localized in the southeast and midwest regions, where there are large investment projects of finishing cattle, exploring business models including custom feeding feedyard, partnerships, and the purchase of lean animals. In each of these situations, decisionmaking between whether or not to invest requires knowledge of several relevant factors, such as the season of year for fattening, slaughter weight (PACHECO et al., 2014a), category for confinement (PACHECO et al., 2014b) and concentrate level
(MISSIO et al., 2009).

Regarding the level of concentrate in the feed supplied to cattle, there is much interest from technicians, producers and investors on aspects of economic feasibility, due to a potential increase in production costs. The Monte Carlo simulation technique is an interesting tool, allowing quantification of the risk associated with investment projects in several fields, including animal production, although this remains little explored. Regarding the simulation methodology, studies in the literature have suggested that random variables (inputs) do not always show independent variation among themselves (TOURAN; WISER, 1992; ALBRIGHT et al., 2010). Pacheco et al. (2014b) estimated a $51 \%$ reduction in risk associated with feedlot-finished steers when simulation was combined with correlation among random input variables. 
Only few studies have quantified the benefits from increasing the accuracy of estimates of simulated financial indicators in beef cattle. These are mainly related to feedlot, which has the particular requirement of high investment, and is also subject to great price fluctuation of commodities involved in the execution of this technology.

Stochastic dominance analysis and sensitivity analysis are other risk assessment techniques related to investment. Studies assessing the economic viability of feedlot cattle have demonstrated that the concentrate fraction is generally more relevant than the roughage fraction (PACHECO et al., 2006; MISSIO et al., 2009; LOPES et al., 2011). Thus, defining the concentrate level in the diet is a critical point of decisionmaking, which may define the success of the activity. This is even more important for the application of feedlot technologies in Brazil, as according to Costa Junior et al. (2013), high levels of concentrate are included in the diet of animals.

The aim of this study was to quantify the risk associated with feedlot finishing zebu bulls fed diets containing different proportions of concentrate, with chopped sugar cane as roughage, using stochastic simulation (Monte Carlo, stochastic dominance and sensitivity analysis) with or without correlations between random variables (components of cost and revenue).

\section{MATERIAL AND METHODS}

The feedlot was conducted in the central region of Goiás state, Brazil ( $16^{\circ} 31^{\prime} 30^{\prime \prime} \mathrm{S} 50^{\circ} 22^{\prime}$ $\left.19^{\prime \prime} \mathrm{W}\right)$, located $620 \mathrm{~m}$ above sea level. According to the Köppen classification, the region has a tropical savanna climate type 'Aw', with rainfall concentrated in summer (October to April) and a dry season in winter (May to September). Analysis of data and stochastic simulations were conducted at the Federal University of Santa Maria, Rio Grande do Sul, Brazil.

Thirty crossbred zebu bulls were used (predominantly Nellore breed, contemporary groupings from the same herd), with an average age and weight of $26 \pm 0.2$ months and $348 \pm 32 \mathrm{~kg}$, respectively. Prior to beginning the finishing phase, the animals were raised on Brachiaria brizantha cv. Marandu, and also received a complete mineral supplement.

The feeding system during the feedlot contained three concentrate ratios based on dry matter (DM), 40, 60 or $80 \%$ DM. The animals were fed twice daily, and their voluntary dietary intake was recorded daily by weighing the amount of food offered and the remaining food from the previous day.

The diet was aimed at an average weight gain of $1.2 \mathrm{~kg} / \mathrm{animal} / \mathrm{day}$, and consisted of chopped sugar cane (1 to $2 \mathrm{~cm}$ pieces) and concentrate, which comprised ground corn grain, $38 \%$ cottonseed meal, urea and a mineral mixture containing monensin. The levels of crude protein and total digestible nutrients were of 11.0 and $70.9 \%$, respectively, for the diet containing $40 \%$ concentrate, 11.5 and $73.9 \%$ for the $60 \%$ concentrate diet and 12.0 and $82.2 \%$, respectively, for the $80 \%$ concentrate diet. For the latter treatment, cottonseed was included in the composition of the concentrate.

The feeding period was 90 days, and the feedlot began in August. The sale of finished cattle occurred in November. The animals were slaughtered when they reached an average age and weight of $29 \pm 0.2$ months and $449 \pm 39 \mathrm{~kg}$, respectively. The average weight gain $(102 \pm 26.2$ $\mathrm{kg})$, dry mater intake $(8.51 \pm 0.29 \mathrm{~kg} /$ day $)$ and subcutaneous fat thickness $(2.2 \pm 1.0 \mathrm{~mm})$ was similar $(\mathrm{p}>0.05)$ between treatments.

Production cost estimates were performed following the methodology described by Pacheco et al. (2014b). The items of costs (purchase of feeder cattle, roughage and concentrate feed, manual labor, health, depreciation and other operational expenses) and income (finished cattle) were associated with the performance characteristics obtained during the feeding period (initial and final weights, average daily weight gain, daily DM intake). The choice of items to compose the cost and revenue were derived from quotes from 12 consecutive years (between 2003 and 2014).

The facility costs were estimated for a static capacity of 1000 animals with a lifespan of 10 years. Details of calculations of depreciation, sanitary control, feed cost, manual labor cost and other operational expenses have been described previously (PACHECO et al., 2014b).

The net present value (NPV; USD/animal) was used as the financial indicator, calculated by $\sum_{i=1}^{n} \frac{\text { values }_{i}}{(1+\text { rate })}$, where $n$ is the number of months, $i$ is the $\mathrm{n}^{\text {th }}$ time period in which money is invested in the project, rate is the minimum rate of attractiveness and values represent the net revenue. Cash flow was prepared for each concentrate level, considering separate investment projects, with a planning horizon of one year, with or without the inclusion of correlation between the input variables.

For the NPV simulation, a cash flow 
including probability distributions of all items of cost and revenue, as well as indicators of livestock, was used. Latin hypercube sampling and a Mersenne Twister random number generator with 2000 iterations were employed for the simulation (PACHECO et al., 2014b).

All estimates were made on a per animal per year basis, deflated for the year 2014 by the general price index (internal availability calculated by the
Getúlio Vargas Foundation). For the purposes of currency conversion, $\mathrm{R} \$ 1.00$ was considered to be equal to USD 0.46 .

Microsoft@ Excel (Redmond, WA, USA), @Risk® (Ithaca, NY, USA) and SAS® System (Cary, NC, USA) software were used for risk assessment, following the steps shown in Figure 1, adapted from Albright et al. (2010).

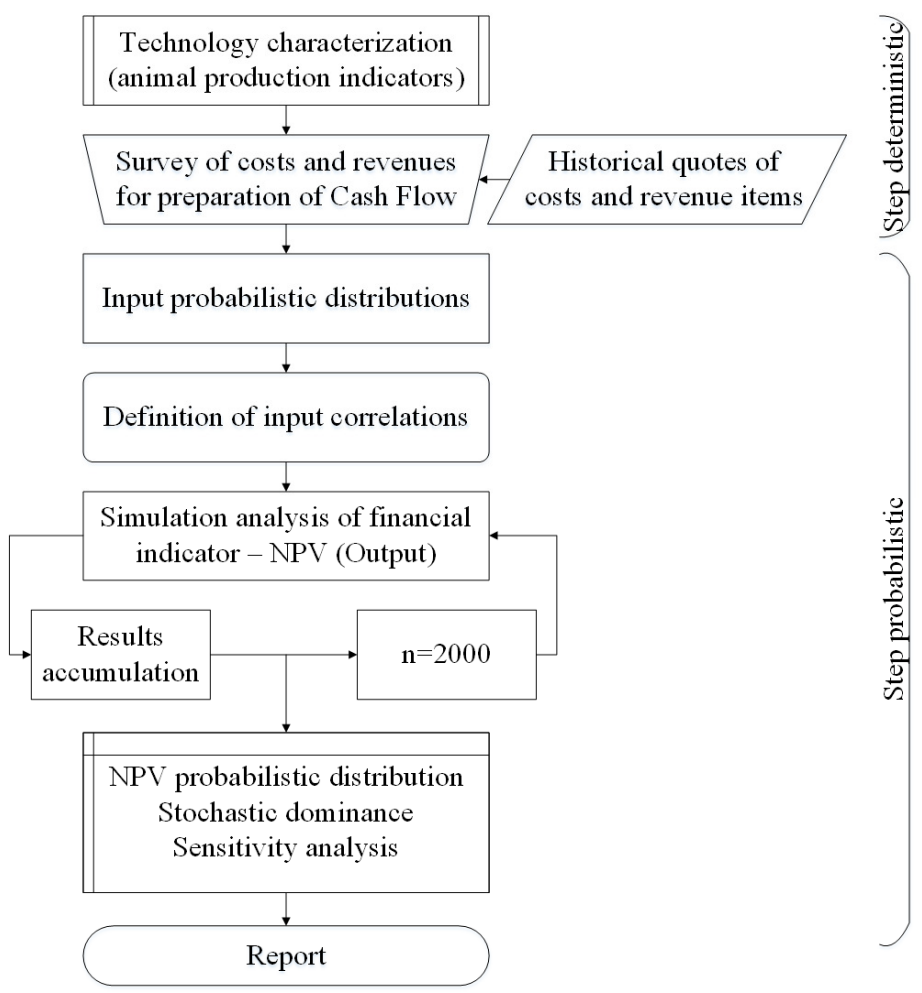

Figure 1. Deterministic and probabilistic steps used in stochastic simulation.

The definition of probability distribution (considering Anderson-Darling test) of items of costs, revenue and technology characterization are presented in Table 1, and Spearman correlations between random input variables in Table 2 .

Table 1. Probability distributions for the items of cost and revenue.

\begin{tabular}{lrl}
\hline Items & Concentrate level & Distributions (parameters*) \\
\hline Feeder steer (USD/@) & $40 ; 60 ; 80$ Weibull $(0.639 ; 0.381)$ \\
Finished steer (USD/@) & $40 ; 60 ; 80$ Extvalue $(1.561 ; 0.174)$ \\
Roughage (USD/kg DM) & $40 ; 60 ; 80$ Extvalue $(0.135 ; 0.020)$ \\
& 40 Extvalue $(0.455 ; 0.116)$ \\
Concentrate (USD/kg DM) & 60 Extvalue $(0.361 ; 0.090)$ \\
& 80 ExtvalueMin $(0.412 ; 0.076)$ \\
Roughage intake & 40 Normal $(5.110 ; 0.173)$ \\
(kg DM/animal/day) & 60 Normal $(3.400 ; 0.116)$ \\
& 80 Normal $(1.700 ; 0.058)$ \\
Concentrate intake & 40 Normal $(3.400 ; 0.116)$ \\
(kg DM/animal/day) & 60 Normal $(5.11 ; 0.173)$ \\
& 80 Normal $(6.810 ; 0.231)$
\end{tabular}


Average weight gain (kg/animal/day)

Initial weight (@)

Final weight (@)

Living wage (USD)

Land (USD)

Depreciation of facilities and equipments

(USD/animal/day)

Depreciation of machinery and implements

(USD/animal/day)

Health (USD/animal)

Minimum rate of attractiveness (\% a.m.)
$40 ; 60 ; 80$ Normal (1.133;0.291)

$40 ; 60 ; 80$ Normal $(11.600 ; 1.110)$

$40 ; 60 ; 80$ Normal $(15.000 ; 1.310)$

$40 ; 60 ; 80$ ExtvalueMin (294.007;37.263)

$40 ; 60 ; 80$ Invgauss (1080.632;737.196)

$40 ; 60 ; 80$ Uniform $(0.017 ; 0.026)$

40; 60; 80 Uniform $(0.007 ; 0.030)$

40; 60; 80 ExtvalueMin (2.352;0.599)

$40 ; 60 ; 80$ Triangular $(0.487 ; 0.585 ; 0.797)$

* Weibull (alpha; beta); Extvalue (alpha; beta); ExtvalueMin (alpha; beta); Normal (mean; standard deviation); Invgauss (mu; lambda); Uniform (minimum; maximum); Triangular (minimum; most likely; maximum).

Table 2. Spearman correlation coefficients of the cost and revenue items according to concentrate level in percentage of dry matter.

\begin{tabular}{cccccccccc}
\hline Items & Concentrate level & 1 & 2 & 3 & 4 & 5 & 6 & 7 & 8 \\
\hline 2 & $40 ; 60 ; 80$ & 0.60 & & & & & & & \\
3 & $40 ; 60 ; 80$ & 0.51 & 0.48 & & & & & & \\
4 & $40 ; 60 ; 80$ & 0.32 & 0.37 & 0.86 & & & & & \\
5 & $40 ; 60 ; 80$ & -0.44 & -0.64 & -0.80 & -0.73 & & & & \\
& 40 & -0.50 & -0.52 & -0.90 & -0.83 & 0.85 & & & \\
6 & $60 ; 80$ & -0.45 & -0.48 & -0.94 & -0.86 & 0.80 & & & \\
& 40 & -0.56 & -0.46 & -0.98 & -0.87 & 0.78 & 0.89 & & \\
7 & $60 ; 80$ & -0.56 & -0.46 & -0.98 & -0.87 & 0.78 & 0.91 & & \\
& 40 & -0.58 & -0.41 & -0.96 & -0.86 & 0.73 & 0.85 & 0.99 & \\
8 & $60 ; 80$ & -0.58 & -0.41 & -0.96 & -0.86 & 0.73 & 0.86 & 0.99 & \\
& 40 & -0.38 & -0.35 & -0.85 & -0.85 & 0.73 & 0.78 & 0.89 & 0.87 \\
9 & $60 ; 80$ & -0.38 & -0.35 & -0.85 & -0.85 & 0.73 & 0.81 & 0.89 & 0.87
\end{tabular}

1 Feeder steer (USD/kg), 2 Finished steer (USD/kg), 3 Living wage (USD/month), 4 Land (USD/ha); 5 Roughage (USD/kg DM), 6 Concentrate (USD/kg DM), 7 Facilities/equipments (USD/animal/day), 8 Machinery/implements (USD/animal/day), 9 Health (USD/animal).

The NPV simulation analysis was performed using the Monte Carlo method with Latin hypercube sampling (MCKAY et al., 1979; IMAN et al., 1981) and a Mersenne Twister random number generator (MATSUMOTO; NISHIMURA, 1998) with 2000 iterations. From this simulation, the probability of NPV occurrences above zero was estimated, specifically the probability of economic viability (MOORE; WEATHERFORD, 2001).

For the evaluation of stochastic dominance, pairs of cumulative probability distributions of simulated NPVs between different concentrate levels were compared according to first- and second-order criteria (HADAR; RUSSEL, 1969;
HANOCH; LEVY, 1969). Significant differences were identified using an asymptotic KolmogorovSmirnov test (CONOVER, 1999).

For the sensitivity analysis, a multivariate stepwise regression method with standardized regression coefficients was used (ALBRIGHT et al., 2010; PALISADE, 2010). The standardized multivariate regression coefficient indicates the number of standard deviations of the NPV that will change with each change of one standard deviation in the input variables, assuming all other input variables remain constant (ALBRIGHT et al., 2010). Statistics related to the variability of input variables are presented in Table 3. 
Table 3. Variability statistics of input variables to all concentrate levels.

\begin{tabular}{lcc}
\hline Input variables & Standard deviation & $\begin{array}{c}\text { Coefficient of variation } \\
(\%)\end{array}$ \\
\hline Concentrate intake, kg DM/day & 0.116 & 3.4 \\
Concentrate, USD/kg DM & 0.0083 & 7.4 \\
Feeder cattle, USD/kg & 4.5752 & 10.2 \\
Final weight, kg & 1.316 & 8.8 \\
Finished cattle, USD/kg & 4.1745 & 8.6 \\
Initial weight, kg & 1.114 & 9.6 \\
Minimum rate of attractiveness, \% a.m. & 0.001 & 10.4 \\
Roughage intake, kg DM/day & 0.174 & 3.4 \\
Roughage, USD/kg DM & 0.0129 & 11.0 \\
\hline
\end{tabular}

\section{RESULTS}

Initially, the simulations to quantify risk were performed both with and without the use of correlation between input variables (Table 4) in order to quantify the change in the simulated NPV.

Minimum and maximum values were greater in the simulation without correlation between input variables when compared to simulation with the correlation included, indicating a higher risk. Regarding the estimated risk, the standard deviation (SD) exceeded the average value of NPV for all simulations. The values of SD differed between simulations with and without correlation, in which the estimated risk to economic viability from the different levels of concentrate was underestimated by $19 \%$ when correlations between the random input variables were not included.

The mean NPV was negative for all treatments, and showed greater economic loss with increasing proportions of concentrate in the diet. The mean value for NPV of all investment projects was USD -62/animal. It appears that the probability when NPV is greater than or equal to zero was low, less than $40 \%$, indicating a high possibility of economic damage for all levels of concentrate tested.

Table 4. Net Present Value statistics (USD/animal), simulated with or without correlation between input variables, according to concentrate level.

\begin{tabular}{lrrrrrr}
\hline Correlation & \multicolumn{3}{c}{ With } & \multicolumn{3}{c}{ Without } \\
\cline { 2 - 7 } Concentrate level & $40 \%$ & $60 \%$ & $80 \%$ & $40 \%$ & $60 \%$ & $80 \%$ \\
\hline Minimum & -586.97 & -470.96 & -578.95 & -696.18 & -831.64 & -696.11 \\
Maximum & 502.77 & 576.73 & 533.08 & 560.17 & 689.57 & 749.24 \\
Mean & -48.83 & -60.19 & -77.00 & -49.06 & -60.16 & -76.76 \\
Standard deviation & 139.23 & 138.61 & 141.40 & 159.99 & 168.24 & 169.92 \\
Coefficient of variation (\%) & 285.11 & 230.30 & 183.64 & 326.09 & 279.65 & 221.38 \\
NPV $\geq 0$ & $33.6 \%$ & $31.4 \%$ & $26.5 \%$ & $37.2 \%$ & $36.0 \%$ & $31.0 \%$ \\
\hline
\end{tabular}

Considering the advantages from including correlations between input variables, the stochastic dominance analysis (Figure 2) was conducted excluding the results obtained from simulation without correlation.

The cumulative probability distribution determined for the NPVs were submitted to a stochastic dominance test, aiming to statistically compare the distribution been pairs of concentrate levels ( $40 \mathrm{vs} .60 \%, 40$ vs. $80 \%$ and 60 vs. $80 \%$ of concentrate), in order to check whether the curves were similar or not. According to the Kolmogorov-Smirnov asymptotic test, there were no significant differences between any two concentrate proportions $(\mathrm{P}>0.05)$, therefore, the response of economic viability and quantification of the risk involved in the confinement activity did not appear to be modified by changing the level of concentrate in the diet offered to animals.

The methodology used for the sensitivity analysis (Figure 3) in this study allows us to compare items with different measurement units, as the regression coefficients are standardized. Similar to the stochastic dominance analysis, only the simulated data with correlation between random input variables was considered in the sensitivity analysis. 


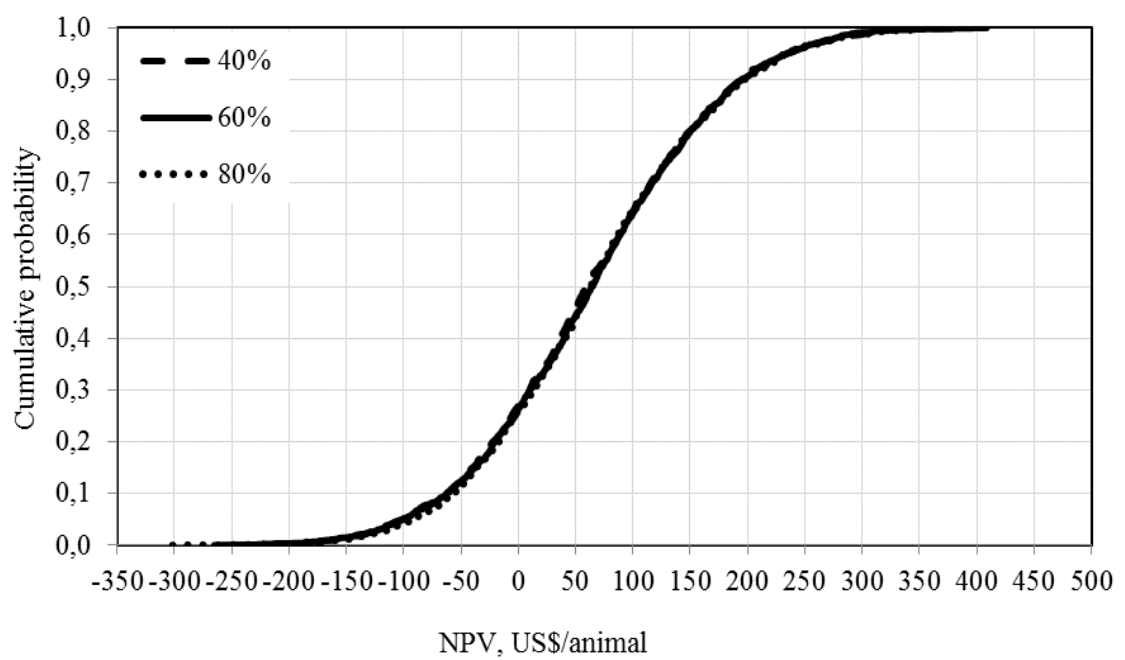

Figure 2. Distribution of cumulative probability in the simulation of Net Present Value (NPV) with correlation between the input variables according to concentrate level.

No expressive differences were observed for the regression coefficients for the different levels of dietary concentrate. This was expected due to the similarity between the distribution of accumulated probability curves observed in Figure 2.

It appears that the final weight (mean of 0.61 ) and the price of finished cattle (mean of 0.60) were the items determined to have the greatest influence on NPV. The price of steers (mean -0.52) and initial weight (mean -0.48) were the third and fourth highest ranking items of importance, followed by the cost of concentrate (mean of -0.047) and concentrate intake (mean -0.027). Finally, the price of roughage (mean -0.018), minimum rate of attractiveness (mean -0.013) and roughage intake (mean -0.007) were the least relevant items influencing the financial indicator NPV.

Roughage intake, kg/day Minimum rate of attractiveness, \% a.m. Roughage, US\$/kg DM Concentrate intake, $\mathrm{kg} /$ day Concentrate, US\$/kg DM Initial weight, $\mathrm{kg}$ Feeder cattle,US\$/@ Finished cattle, US\$/@ Final weight, kg

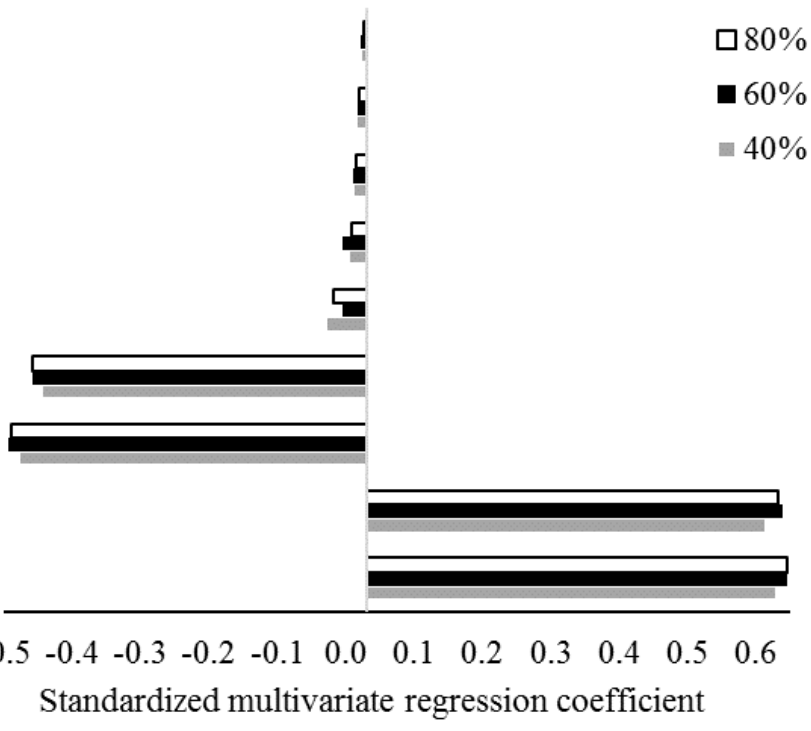

Figure 3. Standardized multivariate regression coefficients of the variables of greater relevance to the Net Present Value simulated, with correlation between the input variables. 


\section{DISCUSSION}

The negative NPV obtained in this study (from 12 consecutive years of quotations) is a worrying result for the use this finishing system in Brazil, considering the increasing number of animals subjected to feedlot finishing in the country (ANUALPEC, 2015).

Although past studies have suggested economic viability (SANTOS; JURCA, 2013) for feedlot-finished cattle, there is general agreement that increasing the level of concentrate in the diet of feedlot cattle also increases the production costs, and consequently, reduced profitability. However, the analysis should consider both animal performance and production costs, particularly as high levels of concentrate are used in the diet of feedlot cattle in major projects in Brazil. According to Millen et al. (2009), in a survey with consulters nutrition, $19.4 \%$ of respondents use between 81 and $90 \%$ concentrate on a DM basis, and $77.4 \%$ of consultants use between 56 and $80 \%$. Excluding the cost of feeder animal purchase, food represents the item with the highest contribution to total cost, of which the concentrate is the most important item. Missio et al. (2009) evaluated Charolais $\times$ Nellore bulls fed diets containing 22, 40, 59 or $79 \%$ concentrate on a DM basis, and reported that the cost of feed exceeded the cost of acquisition of feeder animals fed 59\% concentrate, and verified negative economic viability for bulls fed the diet containing $79 \%$ concentrate.

Although no studies in the literature have estimated the risk of feedlot cattle fed different levels of concentrate, Pacheco et al. (2014b) reported consistent results regarding improved accuracy of estimated risk when correlation was used for evaluating different slaughter ages (22.8 or 15.2 months). According to the authors, who used nine input variables for the probability distribution, the significant reductions in SD ranged from 43 to $57 \%$.

The methodological issues involving the simulation, and consequently, the accuracy of their estimates, have been reported in greater detail in books by Albright et al. (2010) and Palisade (2010), and in studies by Touran and Wiser (1992), Wall (1997) and Yang (2005), however, these all cover different areas of science. Wall (1997) concluded that the type of random distribution of input variables was less relevant than inclusion of the correlation between these variables.

Studies involving stochastic simulation in animal production systems are limited, therefore, there is little data quantifying the improvement in quality simulation in cattle production systems. Thus, simulation techniques with more refined methodologies should be used more frequently in the animal production field. An example is in decision-making, where the probability of occurrence of output variables, represented by the NPV in the present study, is important information for investors.

In the study by Pacheco et al. (2014b), the authors found that reducing the slaughter age (15.2 vs. 22.8 months) of feedlot steers was the most viable alternative for improving investment risk (NPV $\geq 0$ of 80.4 and $62.3 \%$ for 15.2 and 22.8 months, respectively) in the simulation including correlation. For the simulation without correlations, values obtained by the authors were 68.6 and $55.5 \%$ for 15.2 and 22.8 months, respectively. Furthermore, from the probability distribution parameters of the output variable, one can estimate the probability for any interval of values. For example, an investor may choose a NPV value considered attractive for investing in feedlot beef cattle, and from this value, estimate the probability of occurrence of NPV (NPV $\geq$ USD 100/animal was equal to $12 \%$ for the various levels of concentrate in the simulation with correlation). In contrast, other investors may prefer to use the minimum and/or maximum values (Table 4) of the simulated NPV for decision-making. According to Palisade (2010), smaller minimum values indicate a lower possibility of the occurrence of negative values, and therefore, lower risk. The results provided by the simulation can be interpreted differently by different individuals, leading to multiple potential decisions depending on preferences for options, time and risk.

Despite the use of feedlot technologies allowing for high levels of intensification of beef production per unit area, making it an interesting alternative to compete with agriculture, it requires high investment in each production cycle, mainly due to the acquisition of feeder animals and food. As a result, the use of auxiliary tools in decisionmaking is important, allowing the possibility of the success/failure of the economic activity to be quantified. For diets with high levels of concentrate, the risks can be even more evident given the volatility in the price of major grains.

Another alternative for quantifying the risk of the economic viability of feedlot is the sensitivity analysis. As shown in Figure 3, the finished cattle, feeder cattle and the initial and final weights were the items with the greatest influence on the financial indicator in question, exceeding the items related to diet by more than five-times.

Similar results were reported in a study by 
Pacheco et al. (2014a), working with feedlot steers slaughtered at different weights. The price of finished cattle and feeder cattle were the items that most influenced NPV, followed by the price of roughage and concentrate intake. Furthermore, there was a reduction in the value of the linear regression coefficients with increasing slaughter weight for the finished cattle price and feeder cattle price items. For all other items, the coefficients increased with increasing slaughter weight.

The results obtained in this study demonstrate the importance of marketing for cattle feedlot viability. Lopes et al. (2011) commented on the animal selling strategies and other components of production costs, especially those related to agricultural commodities. Among the options available to farmers, the authors highlighted future contracts, direct contracts with the slaughterhouse industry, as well as bonus programs from the breeding associations and retail networks, in order to minimize the effect of price variations in the physical market.

Other items related to diet (price and intake), in addition to the minimum rate of attractiveness, had the lowest influence on NPV. This result draws the attention even in the simulation with $80 \%$ concentrate. This means that the technical efficiency in fattening cattle had less impact on viability than animal marketing strategies. This information has become important for decision-making, particularly as the level of concentrate used in the diet of animals has been continually increasing, as reported by Millen et al. (2009) and Costa Junior et al. (2013).

\section{CONCLUSIONS}

The risk involved with the use of feedlot technology was estimated more accurately by including the correlations among random input variables.

The levels of concentrate evaluated, using chopped sugar cane as roughage, resulted in similar probabilities of economic viability. Furthermore, regardless of the level of concentrate used, the final weight, the finished cattle price, the feeder cattle price and initial weight were the items that had the greatest influence on the financial indicator, followed by intake and the price-related items of diet and minimum rate of attractiveness.

Based on the simulation results, the direct benefit of feedlot can be classified as high risk, suggesting the need for further studies in this area that use Monte Carlo simulation in decision-making.

RESUMO: Estimou-se o risco da viabilidade econômica do confinamento de bovinos zebuínos abatidos com $450 \mathrm{~kg}$ após 90 dias de alimentação, com dietas com diferentes proporções de concentrado na matéria seca (40, 60 ou $80 \%$ ), utilizando simulação de Monte Carlo associado ou não com o uso de correlação de Spearman entre as variáveis aleatórias de entrada, dominância estocástica (DOM) e análise de sensibilidade (SENS). O volumoso utilizado foi cana-deaçúcar picada. Para a simulação do indicador financeiro Valor Presente Líquido (VPL), foi utilizado fluxo de caixa com indicadores de desempenho e distribuição de probabilidade de todos os itens de custos e receitas (anos de 2003 a 2014 ). Amostragem de Hipercubo Latino e gerador de números aleatórios Mersenne Twister foram utilizados para a simulação com 2.000 interações. O risco foi estimado com maior precisão incluindo correlações entre variáveis aleatórias de entrada (probabilidades de VPL $\geq 0 \pm$ desvio padrão foram $35 \pm 166,05 \%$ and $31 \pm 139,75 \%$ para a simulação com e sem correlação, respectivamente). A partir deste resultado, DOM e SENS foram realizadas apenas com correlação entre variáveis aleatórias de entrada. O valor esperado para VPL foi semelhante entre os diferentes níveis de concentrado (média de USD -62 / animal e VPL $\geq 0$ de 33\%), de acordo com a análise de DOM das simulações com correlação. Na SENS, independentemente do nível de concentrado usado, o peso final, os preços do boi gordo e magro e peso inicial foram os itens mais importantes a influenciar o VPL, seguido de consumo da dieta, preços da dieta e taxa mínima de atratividade. Com base nos resultados de simulação, poderia ser classificado o benefício direto de confinamento como de alto risco, sugerindo a expansão dos estudos com uso da técnica de simulação de Monte Carlo na tomada de decisões.

PALAVRAS-CHAVE: Análise de investimento. Projeto de investimento. Análise probabilística. Método estocástico. Correlação de rank.

\section{REFERENCES}

ALBRIGHT, S. C; WINSTON, W. L.; ZAPPE, C. J. Data analysis and decision making. Mason: SouthWestern Cengage Learning, ed. 4, 1080 p., 2010.

ANUALPEC. Anualpec 2015: anuário da pecuária brasileira. São Paulo: Informa Economics FNP, 2015. 280 p. 
COSTA JUNIOR, C; GOULART, R. S.; ALBERTINI, T. Z.; FEIGL, B. J.; CERRI, C. E. P.; VASCONCELOS, J. T.; BERNOUX, M.; LANNA, D. P. D.; CERRI, C. C. Brazilian beef cattle feedlot manure management: a country survey. J Anim Sci, Champain, v. 91, n. 4, p. 1811-1818, 2013.

CONOVER, W. J. Practical nonparametric statistics. 3. ed. New York: John Wiley and Sons, 1999. 592 p.

HADAR, J.; RUSSELL, W. R. Rules for ordering uncertain prospects. Am Econ Rev, Pittsburgh, v. 59, p. 2534, 1969.

HANOCH, J.; LEVY, H. The efficiency analysis of choices involving risk. Am Econ Rev, Pittsburgh, v. 74, p. 335-346, 1969. https://doi.org/10.2307/2296431

IMAN, R. L.; HELTON, J. C.; CAMPBELL, J. E. An approach to sensitivity analysis of computer models, Part 1. Introduction, input variable selection and preliminary variable assessment. J Qual Tech, Milwaukee, v. 13, n. 3, p. 174-183, 1981.

LOPES, L. S.; LADEIRA, M. M.; MACHADO NETO, O. R.; SILVEIRA, A. R. M. C.; REIS, R. P.; CAMPOS, F. R. Viabilidade econômica da terminação de novilhos nelore e red norte em confinamento na região de Lavras-MG. Rev Cien Agro, Lavras, v. 35, n. 4, p. 774-780, 2011.

MILLEN, D. D.; PACHECO, R. D. L.; ARRIGONI, M. D. B.; GALYEAN, M. L.; VASCONCELOS, J. T. A snapshot of management practices and nutritional recommendations used by feedlot nutritionists in Brazil. $\mathbf{J}$ Anim Sci, Champain, v. 87, p. 3427-3439, 2009.

MATSUMOTO, M.; NISHIMURA, T. Mersenne twister: a 623-dimensionally equidistributed uniform pseudorandom number generator. ACM T Model Comput S, New York, v. 8, n. 1, p. 3-30, 1998.

MCKAY, M. D.; BECKMAN, R.J.; CONOVER, W. J. A Comparison of three methods for selecting values of input variables in the analysis of output from a computer code. J Am Stat Assoc, Alexandria, v. 21, n. 2, p. 239-245, 1979. https://doi.org/10.1080/00401706.1979.10489755

https://doi.org/10.2307/1268522

MISSIO, R. L.; BRONDANI, I. L.; FREITAS, L. S.; SACHET, R. H.; SILVA, J. H. S.; RESTLE, J. Desempenho e avaliação econômica da terminação de tourinhos em confinamento alimentados com diferentes níveis de concentrado na dieta. Rev Bras Zoot, Brasília, v. 38, p. 1309-1316, 2009.

https://doi.org/10.1590/s1516-35982009000700021

MOORE, J. H.; WEATHERFORD, L. R. Decision Modeling with Microsoft Excel. Upper Saddle River: Prentice Hall, 2001. 704 p.

PACHECO, P. S.; RESTLE, J.; OLEGARIO, J. L.; MENEZES, F. R.; VAZ, F. N.; PASCOAL, L. L.; LEMES, D. B.; VALENÇA, K. G.; MACHADO, G. I. O.; RODRIGUES, A. C. T. Correlation and slaughter weight on sensitivity analysis of charolais steers feedlot finished. AIJCR, New York, v. 4, p. 28-34, 2014a.

PACHECO, P. S.; RESTLE, J.; PASCOAL, L. L.; VAZ, F. N.; VAZ, R. Z.; VALENCA, K. G.; OLEGARIO, J. L. Use of correlation between input variables in estimating the risk of feedlot finishing of steers and young steers. An Acad Bras Cien, Rio de Janeiro, v. 86, p. 945-954, 2014b.

PACHECO, P. S.; RESTLE, J.; VAZ, F. N.; FREITAS, A. K.; PADUA, J. T.; NEUMANN, M.; ARBOITTE; M. Z. Avaliação econômica da terminação em confinamento de novilhos jovens e superjovens de diferentes grupos genéticos. Rev Bras Zoot, Brasília, v. 35, n. 1, p. 309-320, 2006. https://doi.org/10.1590/S151635982006000100039

PALISADE. @ RISK: Risk analysis and simulation add-in for Microsoft@ Excel. Ithaca: Palisade, 2010. $739 \mathrm{p}$. 
SANTOS, D. F. L.; JURCA, F. L. Analysis of investment in feedlot cattle in the central-western Brazil: a case study. Custos e @ gronegócio on line, Pernambuco, v. 9, p. 129-161, 2013.

TOURAN, A.; WISER, E. P. Monte Carlo technique with correlated random variables. J Const Eng M Asce, New York, v. 118, p. 258-272, 1992.

WALL, D. M. Distributions and correlations in Monte Carlo simulation. Constr Manage Econ, Grand Forks, v. 15, p. 241-258, 1997. https://doi.org/10.1080/014461997372980

YANG, I. T. Simulation-based estimation for correlated cost elements. Int J Proj Manag, kidlington, v. 23, p. 275-282, 2005. 